\title{
PENGARUH PROFITABILITAS, LEVERAGE, DAN LIKUIDITAS TERHADAP NILAI PERUSAHAAN SUB SEKTOR FOOD AND BEVERAGES
}

\author{
I Putu Sukarya ${ }^{1}$ \\ I Gde Kajeng Baskara ${ }^{2}$
}

\author{
${ }^{1,2}$ Fakultas Ekonomi dan Bisnis Universitas Udayana, Bali, Indonesia \\ e-mail: iputusukarya04@gmail.com
}

\begin{abstract}
ABSTRAK
Nilai perusahaanmenjadi penting karena menunjukkan kinerja perusahaan yang berpengaruh terhadap persepsi investor terhadap perusahaan. Tujuan penelitian adalah untuk mengetahui pengaruh profitabilitas, leverage, dan likuiditas terhadap nilai perusahaan. Metode pengumpulan sampel pada penelitian ini menggunakan pendekatan non-probability sampling dengan teknik purposive sampling. Jumlah sampel penelitian yaitu sebanyak 12 perusahaan pada sektor food and beverages di Bursa Efek Indonesia tahun 2014-2016. Hasil penelitian menunjukkan bahwa secara simultan profitabilitas berpengaruh signifikan terhadap nilai perusahaan, leverage berpengaruh signifikan terhadap nilai perusahaan, dan likuiditas berpengaruh signifikan terhadap nilai perusahaan. Secara parsial profitabilitas berpengaruh positif signifikan terhadap nilai perusahaan, Leverage berpengaruh negatif tidak signifikan terhadap nilai perusahaan, dan Likuiditas berpengaruh positif signifikan terhadap nilai perusahaan.
\end{abstract}

Kata kunci : nilai perusahaan, profitabilitas, leverage, dan likuiditas

\begin{abstract}
The firm value is important because it reflects the performance of the company that affect the perception of investors to the company. The purpose of the study is to determine the effect of profitability, leverage, and liquidity to the firm value. Sampling method used in this research is non-probability sampling approach with purposive sampling technique. The number of samples are 12 companies in the food and beverages sector in Indonesia Stock Exchange 2014-2016. The results showed that simultaneously profitability have significant influence to firm value, leverage have significant influence to firm value, and liquidity have significant influence to firm value. Partially profitability has a positive influence significantlyto firm value, Leverage has negative influence not significanlyt to firm value, and Liquidity has a positive influence significant to firm value.
\end{abstract}

Keywords: firmvalue, profitability, leverage, and liquidity 
I Putu Sukarya, Pengaruh Profitabilitas, Leverage, dan Likuiditas...

\section{PENDAHULUAN}

Persaingan bisnis yang sangat ketatdi era globalisasi pada kurun waktu ini tidak bisa terlepaskan dari adanya pengaruh perkembangan lingkungan politik, ekonomi, sosial, serta kemajuan teknologi. Perusahaan diharapkanmampu mengelola fungsi-fungsi manajemen yang dimiliki dengan baik sehingga mampu menyesuakan diri dan mampu membaca situasi yang terjadi. Perusahaan yang mampu bersaing dan unggul tentunya harus memiliki kinerja yang baik agar dapat mempertahankan eksistensinya. Perusahaan dapat mencerminkan kinerjanya melalui nilai perusahaan. Para investor akan tertarik untuk berinvestasi ketika nilai perusahaan tinggi dan hal ini akan berdampak pada tingginya harga saham perusahaan.

Nilai perusahaan merupakan harga yang bersedia dibayar oleh calon pembeli apabila perusahaan tersebut dijual (Husnan dan Pudjiastuti, 2012:6). Nilai perusahaan sangat penting karena mencerminkan kinerja perusahaan yang dapat mempengaruhi persepsi investor terhadap perusahaan. Nilai perusahaan yang tinggi akan membuat pasar percaya tentang keadaan perusahaan saat ini ataupun prospek perusahaan di masa depan (Wijaya dan Sedana, 2015). Salah satu indikator nilai perusahaan dapat dilihat dari besarnya saham yang diterbitkan oleh perusahaan di pasar modal. Harga saham suatu perusahaan yang semakin tinggi akan menyebabkan tingginya nilai perusahaanya yang berdampak pada makin besarnya kemakmuran pemilik perusahaan.

Price to book value adalah salah satu alat ukur yang dapat digunakan untuk mengukur nilai perusahaan. Price to book value merupakan perbandingan antara 
harga saham dengan nilai buku per lembar saham. Tingkat kemakmuran yang tinggi bagi pemegang saham tercermin dari tingginya price to book value yang dimiliki perusahaan. Tujuan utama dari suatu perusahaan adalah membuat makmur para pemegang sahamnya. Nilai perusahaan dapat ditingkatkan dengan memperhatikan faktor-faktor internal dan eksternal perusahaan. Faktor internal perusahaan dapat berupa rasio-rasio yang tercatat dalam laporan keuangan perusahaan seperti profitabilitas, leverage, dan likuiditas, sedangkan faktor eksternal perusahaan yaitu faktor-faktor dari luar perusahaan yang dapat mempengaruhi perusahaan itu sendiri, seperti nilai kurs, inflansi, dan pertumbuhan pasar.

Menurut Hartono (2013) profitabilitas merupakan salah satu variabel yang mempengaruhi nilai perusahaan dari beberapa variabel yang di uji. Perusahaan yang mampu membukukan laba yang meningkat mengindikasikan bahwa perusahaan tersebut mampu melakukan kinerja dengan baik sehingga dapat meningkatkan harga saham perusahaan dan menciptakan tanggapan yang positif dari investor. Profitabilitas pada penelitian ini diukur dengan return on equity (ROE) yang menunjukkan seberapa besar kemampuan memperoleh laba diukur dari modal sendiri maupun dari seluruh dana yang diinvestasikan ke dalam perusahaan. Sucuahi dan Cambarihan (2014) menemukan bahwa profitabilitas dapat meningkatkan nilai perusahaan yang dapat dilihat hasil pengujian yang menunjukkan bahwa adanya pengaruh positif signifikan antara profitabilitas terhadap nilai perusahaan. Hasil temuan ini didukung oleh penelitiaan lain seperti: Wijaya dan Linawati (2015), Pramana dan Mustanda (2016),serta Winarto (2015). 
I Putu Sukarya, Pengaruh Profitabilitas, Leverage, dan Likuiditas...

Perbedaan hasil penelitian ditemukan oleh Moghadas et al. (2013) serta Chetty et al. (2015) yangmenemukan bahwa profitabilitas tidak memiliki pengaruh signifikan terhadap nilai perusahaan. Munawaroh dan Priyadi (2014) serta Herawati (2013) menemukan bahwa profitabilitas memiliki pengaruh negatif dan signifikan terhadap nilai perusahaan.

Leverage merupakan rasio keuangan yang digunakan untuk mengukur pendanaan suatu perusahaan yang berasal dari utang. Leverage juga memiliki arti suatu kemampuan perusahaan dalam melunasi kewajiban finansial yang dimiliki baik dalam jangka pendek maupun dalam jangka panjang (Wiagustini, 2013:76). Leverage pada penelitian ini diukur dengan menggunakan Debt to Equity Ratio (DER) karena rasio ini mengukur kemampuan perusahaan untuk mengembalikan biaya utang melalui modal yang dimiliki. Penelitian yang dilakukan oleh Winarto (2015) serta Adegnuba et al. (2016) menunjukkan bahwa Leverage berpengaruh positif signifikan terhadap nilai perusahaan. Penelitian serupa ditemukan oleh Isaac (2014), Asif dan Aziz (2016), Riaz dan Qasim (2016), dan Prastuti dan Sudiarta (2016). Perbedaanpenelitian ditemukan olehGill dan Obradovich(2012), Sulong et al. (2013), Rasyid (2015), Ramadan (2015), Priya et al. (2015), serta Ha dan Tai (2017) yang menemukan bahwa adanya pengaruh negatif antara leverage terhadap nilai perusahaan. Kodongo et al. (2014) serta Novari dan Lestari (2016) menemukan bahwa leverage tidak berpengaruh signifikan terhadap nilai perusahaan.

Likuiditas merupakan suatu kemampuan perusahaan didalam memenuhi kewajiban-kewajiban jangka pendek yang dimiliki.Nilai current ratio (CR) dan 
quick ratio $(\mathrm{QR})$ yang semakin tinggi menunjukkan perusahaan memiliki tingkat likuidasi yang baik sehingga dapat meningkatkan nilai perusahaan di mata investor serta memberikan persepsi yang positif terhadap kondisi perusahaan. Penelitian ini menggunakan current ratiokarena rasio inimerupakan alat ukur likuiditas yang paling lancar. Penelitian yang dilakukan oleh Putra dan Lestari (2016) mendapatkan hasil bahwa adanya pengaruh positif dan signifikan antara likuiditas terhadap nilai perusahaan, hal ini berarti investor akan tertarik pada perusahaan yang memiliki tingkat likuiditas yang baik. Penelitian $\mathrm{Du}$ et al. (2016)menemukan pengaruh positif signifikan likuiditas terhadap nilai perusahaan. Perbedaan hasil penelitian ditemukan oleh Wijanti dan Sedana (2013), sertaWinarto (2015) yang menemukan bahwa likuiditas berpengaruh negatif signifikan terhadap nilai perusahaan.

Penelitian ini dilakukan pada perusahaan sektor food and beverages di Bursa Efek Indonesia periode 2014-2016. Sektor food and beverage dipilih karena pertumbuhan perusahaan makanan dan minuman semakin pesat diberbagai daerah indonesia. Berbagai macam bisnis yang dapat dijadikan investasi dalam bentuk saham salah satunya adalah bisnis dibidang food and beverage (bidang makanan dan minuman). Sektor food and beverage dipilih sebagai alat analisis karena memegang peranan penting dalam memenuhi kebutuhan konsumen karena sektor food and beverages bergerak dalam bidang konsumsi.

Meningkatnya pertumbuhan jumlah penduduk di Indonesia memberikan dampak pada meningkatnya kebutuhan masyarakat terhadap makanan dan minuman. Karakteristik masyarakat yang gemar berbelanja makanan, dapat 
I Putu Sukarya, Pengaruh Profitabilitas, Leverage, dan Likuiditas...

membantu dalam mempertahankan sektor dengan baik. Ini mengakibatkan investor tertarik untuk menanamkan modalnya pada sektor food and beverage karena prospek yang cukup bagus dan cenderung diminati oleh investor.

Tabel 1.

Data Nilai PerusahaanSub Sektor Food and Beveragesdi BEI Periode 2014-2016

\begin{tabular}{cllccc}
\hline \multirow{2}{*}{ No } & \multirow{2}{*}{ Kode } & & \multicolumn{2}{c}{ Price Book Value (persen) } \\
\cline { 4 - 6 } & & 2014 & $\mathbf{2 0 1 5}$ & $\mathbf{2 0 1 6}$ \\
\hline 1 & AISA & Tiga Pilar Sejahtera Food Tbk. & 205 & 98 & 158 \\
2 & CEKA & Wilmar Cahaya Indonesia Tbk. & 87 & 63 & 94 \\
3 & DLTA & Delta Djakarta Tbk. & 933 & 490 & 437 \\
4 & ICBP & Indofood CBP Sukses Makmur Tbk. & 526 & 479 & 561 \\
5 & INDF & Indofood Sukses Makmur Tbk. & 145 & 105 & 155 \\
6 & MLBI & Multi Bintang Indonesia Tbk. & 4867 & 2254 & 4754 \\
7 & MYOR & Mayora Indah Tbk. & 474 & 525 & 638 \\
8 & ROTI & Nippon Indosari Corpindo Tbk. & 776 & 539 & 597 \\
9 & SKBM & Sekar Bumi Tbk. & 308 & 257 & 165 \\
10 & SKLT & Sekar Laut Tbk. & 136 & 168 & 127 \\
11 & STTP & Siantar Top Tbk. & 480 & 392 & 382 \\
12 & ULTJ & Ultrajaya Milk Industri \& Trading Co. Tbk. & 491 & 407 & 395 \\
Rata-Rata & & 785,6 & 481,4 & 705,2 \\
\hline \multicolumn{3}{l}{ Sumber $:$ Data Diolah, 2018 }
\end{tabular}

Berdasarkan laporan statistik tahunan IDX yang dipublikasikan oleh website resmi IDX yang diolah selama periode penelitian 2014-2016 menunjukkan bahwa perolehan rata-rata Price to Book Value (PBV) pada sub sektor food and beverages mengalami fluktuasi selama periode penelitian dengan nilai 785,6 persen pada tahun $2014,481,4$ persen pada tahun 2015 , dan 705,2 persen pada tahun 2016.

PBV tiap tahun perusahaan food and beverages tersebut berfluktuasi, namun ada empat perusahaan yang memiliki nilai PBV mengalami penurunan dua tahun berturut-turut. Perusahaan tersebut adalah Deltajaya Djakarta TBk., Nippon Indosari Corpindo Tbk.,Sekar Bumi Tbk., Siantar Top Tbk., dan Ultrajaya Milk Industry \& TradingCo. Tbk. Hal tersebut menunjukkan bahwa nilai perusahaan di sub sektor food and beverages tersebut tidak seluruhnya mengalami peningkatan, 
sehingga perlu dilakukan penelitian lebih lanjut mengenai faktor-faktor apa saja yang memengaruhi penurunan PBV tersebut. Faktor-faktor yang berpengaruh terhadap PBV antara lain profitabilitas, leverage, dan likuiditas.

Berdasarkan latar belakang tersebut maka permasalahan yang akan diteliti adalah bagaimana pengaruh yang diakibatkan oleh variabel profitabilitas, leverage, dan likuiditas terhadap nilai perusahaan. Hasil penelitian ini akan menunjukkan apakah terjadi perbedaaan hasil penelitian antara penelitian terdahulu. Hal ini yang menjadi acuan pentingnya penelitian sehingga perlu dikaji atau dilakukan penelitian lebih lanjut dengan objek penelitian yaitu perusahaan sub sektor food and beverages yang terdaftar di BEI periode 2014-2016.

Berdasarkan latar belakang di atas maka yang menjadi pokok permasalahan dalam penelitian ini adalah: 1) Bagaimana pengaruh profitabilitas terhadap nilai perusahaan?, 2) Bagaimana pengaruh leverage terhadap nilai perusahaan?, dan 3) Bagaimana pengaruh likuiditas terhadap nilai perusahaan?. Penelitian ini bertujuan untuk mengetahui pengaruh dari masing-masing variabel, seperti: pengaruh profitabilitas terhadap nilai perusahaan, pengaruhleverage terhadap nilai perusahaan, serta pengaruh likuiditas terhadap nilai perusahaan.

Nilai perusahaan adalah nilai nyata yang dimiliki perusahaan yang mengambarkan persepsi investor terhadap emitmen tertentu, sehingga nilai perusahaan merupakan persepsi investor terhadap perusahaan yang dikaitkan dengan harga saham.Nilai perusahaan pada penelitian ini didasarkan pada price to book value (PBV) yang dapat diartikan sebagai perbandingan antara harga saham 
I Putu Sukarya, Pengaruh Profitabilitas, Leverage, dan Likuiditas...

dengan nilai buku saham. Berdasarkan dari perbandingan tersebut dapat diketahui harga saham perusahaan berada di atas atau dibawah nilai buku saham tersebut.

Profitabilitas merupakan rasio keuangan yang menunjukkan keberhasilan suatu perusahaan untuk memperoleh keuntungan. Profitabilitas suatu perusahaan dapat diukur dengan melihat nilaireturn on equity (ROE). Return on equity menunjukkan tingkat dari hasil pengembalian investasi bagi pemegang saham. Perusahaan dapat menarik minat investor untuk menanamkan modalnya di perusahaan dengan menunjukkan bahwa perusahaan memiliki nilai profitabilitas yang tinggi. Tingginya nilai dari ROE akan dapat meningkatkan harga saham perusahaan, dan oleh sebab itu makaminat investor untuk menanamkan modal yang dimiliki akan semakin meningkat.Tingginya harga saham yang dapat mempengaruhi nilai perusahan mencerminkan adanya hubungan yang positif antara profitabilitas dengan harga saham.Profitabilitas perusahaan yang tinggi juga akan meningkatkan laba perlembar saham (EPS/Earning Per Share) perusahaan. Nilai EPS yang meningat akan membuat investor tertarik untuk menanamkan modalnya dengan cara membeli saham perusahaan. Profitabilitas juga dapat menggambarkan kinerja perusahaan dalam mengelola manajemen yang dimiliki. Besarnya minat investor dalam membeli saham yang dimiliki perusahaan akan dapat membuat harga saham perusahaan tersebut mengalami peningkatan kemudia ini akan berimbas pada meningkatnya nilai perusahaan. Penelitian yang dilakukan oleh Sucuahi dan Cambarihan (2014), Nofrita (2013), Risqia et al. (2013),serta Winarto (2015) menemukan bahwa profitabilitas memiliki pengaruh 
positif terhadap nilai perusahaan. Berdasarkan pemaparan diatas maka dapat dikemukakan hipotesis penelitian sebagai berikut.

$\mathrm{H}_{1}$ : Profitabilitas berpengaruh positif signifikan terhadap nilai perusahaan.

Sebuah perusahaan dikatakan tidak solvable apabila total utang perusahaan lebih besar dari pada total modal yang dimiliki perusahaan.Perbandingan jumlahutang yang lebih besar akan membuat nilai perusahaan juga semakin tinggi karena diakibatkan oleh adanya pengelolaan utang yang baik, namun meningkatnya jumlah utang pada titik tertentu akan dapat menurunkan nilai perusahaan akibat dari biaya yang ditimbulkan dari peminjaman utang yang lebih besar daripada manfaat yang diperoleh dari utang tersebut. Hasil penelitian ini mendukung penelitian yang dilakukan oleh Dewi dan Wirajaya (2013), Winarto (2015), serta Adegnuba et al. (2016) yaituleverage memiliki pengaruh positif signifikan terhadap nilai perusahaan.

$\mathrm{H}_{2}$ : Leverage berpengaruh positif signifikan terhadap nilai perusahaan.

Likuiditas dapat dikatakan sebagai salah satu faktor yang digunakan untuk mengukur kemampuan perusahaan membayar kewajiban-kewajiban yang harus diselesaikan. Hal tersebut akan memberikan dampak besar pada nilai perusahaan di hadapan para investor dalam mengambil keputusan. Tingkat likuiditas yang tinggi menunjukkan bahwa perusahaan berada dalam kondisi yang baik yang mampu memenuhi kewajiban jangka pendeknya. Harga saham yang meningkat tentunya akan meningkatkan nilai dari perusahaan. Likuiditas yang semakin tinggi akan menyebabkan nilai perusahaan menjadisemakintinggidansebaliknya semakinrendahlikuiditasmaka nilai perusahaan akan menjadi semakin rendah. 
I Putu Sukarya, Pengaruh Profitabilitas, Leverage, dan Likuiditas...

Penelitian yang dilakukan Winarto (2015) menemukan bahwa likuiditas berpengaruh positif terhadap nilai perusahaan pada penelitian yang dilakukan 32 perusahaan manufaktur yang terdaftar di BEI periode 2005-2010.Putra danLestari (2016)juga menyatakan likuiditas berpengaruh positif pada nilai perusahaan pada perusahaan manufaktur yang terdaftar di BEI. Hasil penelitian ini juga didukung oleh penelitian lainnya seperti Anzlina dan Rustam (2013) sertaJariah (2016). Berdasarkan pemaparan diatas maka dapat dikemukakan hipotesis penelitian sebagai berikut.

$\mathrm{H}_{3}$ : Likuiditas berpengaruh positif signifikan terhadap nilai perusahaan.

\section{METODE PENELITIAN}

Pendekatan yang digunakan dalam penelitian ini adalah pendekatan kuantitatif yang bersifat asosiatif, dimana desain penelitian ini menggunakan hubungan kausal. Hubungan kausal merupakan suatu hubungan sebab akibat antara variabel satu dengan variabel yang lainnnya. Penelitian ini dilakukan agar dapat mengetahui pengaruh profitabilitas, leverage, dan likuiditas terhadap nilai perusahaan pada perusahaan sub sektor food and beverages di Bursa Efek Indonesia (BEI) pada periode 2014-2016. Variabel dependen (variabel terikat) dalam penelitian ini yaitu nilai perusahaan dan variabel independen (variabel bebas) yaitu Profitabilitas $\left(\mathrm{X}_{1}\right)$, Leverage $\left(\mathrm{X}_{2}\right)$, dan Likuiditas $\left(\mathrm{X}_{3}\right)$.

Nilai perusahaan dapat diukur dengan PBV (Price Book Value) yang merupakan rasio pasar yang digunakan untuk mengukur kinerja harga pasar saham terhadap nilai buku per lembar saham perusahaan. Rasio ini menunjukkan seberapa jauh suatu perusahaan mampu menciptakan nilai perusahaan yang relatif 
terhadap jumlah modal yang diinvestasikan. PBV diukur dengan membandingkan nilai saham perusahaan dengan nilai buku per lembar saham tersebut. PBV memiliki satuan persentase dan dihitung dengan rumus berikut.

$$
\mathrm{PBV}=\frac{\mathrm{N} \quad \mathrm{S} \tilde{\mathrm{e}}}{\mathrm{N} \quad \mathrm{B} \quad \mathrm{P} \quad \mathrm{Lt} \quad \mathrm{S} \tilde{\mathrm{e}}} \times 100 \%
$$

Profitabilitas merupakan kemampuan perusahaan dalam memperoleh laba perusahaan (profit) dari usaha bisnis yang dilakukan.Profitabilitas dihitung menggunakan return on equity (ROE) dengan menggunakan satuan presentase. ROE dihitung dengan cara membandingkan total earning after tax(EAT) dengan total equity dengan rumus.

$$
\text { Return on equity }(\mathrm{ROE})=\frac{\text { EAT }}{\text { Total Ekuitas }} \times 100 \%
$$

Leverage merupakan salah satu bagian dalam pendanaan perusahaan yang berbentuk utang yang digunakan untuk memenuhi kewajiban jangka panjang maupun jangka pendek perusahaan. Leverage suatu perusahaan yang semakin tinggi dapat menyebabkan semakin besar risiko kerugian yang ditanggung perusahaan, tetapi kesempatan mendapatkan keuntungan juga menjadi semakin tinggi. Leveragediukur menggunakan satuan presentase dengan membandingkan antara total utang dengan total ekuitas.

$$
\text { Debt to Equity Ratio }(\mathrm{DER})=\frac{\mathrm{T}}{\mathrm{M}} \mathrm{\textrm {S }}-x 100 \%
$$

Likuiditas merupakan kemampuan perusahaan dalam memenuhi kewajiban finansialnya dalam jangka pendek menggunakan dana lancar yang. Likuiditas dapat diukur mengunakan current ratio (CR) dengan cara membandingkan antara 
aktiva lancar dengan utang lancar. Adapun satuan dari current ratio(CR) adalah persentase dihitung dengan rumus.

$$
\text { Current ratio }=\frac{A}{K} \times 100 \%
$$

Populasi dalam penelitian ini yaitu seluruh perusahaan sub sektor food and beverages di Bursa Efek Indonesia periode 2014-2016 dengan jumlah populasi sebanyak 14 perusahaan.Metode pengumpulan sampel yang digunakan pada penelitian ini adalah pendekatan non-probability sampling dengan teknik purposive sampling. Sampel pelitian ini sesuai dengan tujuan penelitian yaitu untuk mengetahui pengaruh dari profitabilitas, leverage,dan likuiditas terhadap nilai perusahaan yang mengacu pada syarat pemilihan sampel. Syarat pemilihan sampel tersebut adalah perusahaan yang memiliki nilai profitailitas yang bernilai positif agar menghasilkan nilai yang tidak bias. Berdasarkan persyaratan tersebut maka didapatkan sampel sebanyak 12 perusahaan yang digunakan dalam penelitian ini.

Data kuantitatif dalam penelitian ini yaitu laporan keuangan perusahaan yang berupa laporan neraca tahunan perusahaan manufaktur sub sektor food and beverages yang terdaftar di Bursa Efek Indonesia (BEI) periode 2014-2016. Data kualitatif merupakan data yang tidak dapat diukur dalam skala numerik, data kualitatif dalam penelitian ini adalah gambaran umum mengenai perusahaan manufaktur sub sektor food and beverages yang terdaftar di Bursa Efek Indonesia periode 2014-2016.Berdasarkan sumbernya, data yang diperoleh bersumber dari data sekunder, data sekunder adalah data yang telah dikumpulkan oleh pihak lain, dalam hal ini adalah data yang telah di publikasi oleh perusahaan sub sektor food 
and beverages yang terdaftar di Bursa Efek Indonesia (BEI) berupa laporan neraca keuangan tahunan yang telah diolah pada periode 2014-2016. Metode yang digunakan dalam penelitian ini adalah metode observasi non participant, metode ini dilakukan dikarenakan peneliti tidak terlibat langsung dalam aktivitas yang diteliti melainkan hanya memposisikan diri sebagai pengamat yaitu dengan melakukan observasi terhadap dokumen atau laporan keuangan perusahaan pada perusahaan sub sektor food and beverages yang terdaftar di Bursa Efek Indonesia (BEI) periode 2014-2016.

Teknik analisis data pada penelitian ini menggunakan model regresi berganda dengan menggunakan program SPSS versi 20. Teknik ini digunakan untuk menjelaskan hubungan antara variabel-variabel bebas yaitu profitabilitas, leverage, dan likuiditas dengan variabel terikat adalah nilai perusahaan. Berikut akan dijelaskan analisis regresi linier berganda yang akan digunakan dalam penelitian ini.Uji asumsi klasik terdiri dari uji normalitas, multikolineariaritas, autokolerasi, dan heteroskedastisitas.

Uji normalitas memiliki tujuan untuk menguji apakah dalam model regresi, variabel pengganggu atau residual memiliki distribusi normal. Uji normalitas dilakukan dengan uji One-Sample Kolmogorof-Smirnov Test (One K-S) yang diterapkan pada residual hasil uji regresi. Jika assymp sig. dari nilai residual lebih besar dari $\alpha(0,05)$ maka dapat disimpulkan bahwa data terdistribusi normal.

Uji multikolinearitas bertujuan untuk menguji apakah pada model regresi ditemukan adanya korelasi antara variabel bebas. Model regresi yang baik seharusnya tidak terjadi korelasi diantar variabel bebas. Jika nilai tolerance $\leq 0.01$ 
atau sama dengan nilai VIF (Variance Inflation Factor) $\geq 10$, maka model regresi terdapat multikolinieritas.

Uji autokorelasi digunakan untuk mengetahui model yang terdapat dalam regresi linearapakah memiliki korelasi diantara kesalahan penggangu pada periode $\mathrm{t}$ dengan kesalahan pengganggu pada periode t-1 (sebelumnya). Autokorelasi munculkarena adanya observasi yang berurutan sepanjang waktu yang berkaitan antara satu sama lain (time series). Timbulnya masalah iniakibat dari residual tidak bebas dari satu observasi ke observasi yang lainnya. Model regresi yang baik yaitu model regresi yang bebas dari adanya autokorelasi. Pendeteksian atas ada atau tidaknya autokorelasi dalam penelitian ini yaitu dengan menggunakan uji Durbin-Watson (DW). Pengambilan keputusan dilakukan dengan melihat jumlah sampel yang diteliti dan kemudian melihat angka ketentuannya pada tabel DurbinWatson. Proses pengambilan keputusan mengenai ada atau tidaknya autokorelasi pada suatu model adalah sebagai berikut:

a. $d u<d<4-d u \rightarrow$ memiliki arti tidak ada autokorelasi.

b. $0<\mathrm{d}<\mathrm{dl}<\mathrm{d}<4$ atau $4-\mathrm{dl}<\mathrm{d}<4 \rightarrow$ memiliki arti ada autokorelasi.

c. dl $\leq d$ sluatau 4-du $\leq d \leq 4-d l \quad \rightarrow$ memiliki arti tidak ada keputusan.

Uji heteroskedastisitas digunakan untuk mengetahui terjadinya ketidaksamaan variance dari residual satu pengamatan ke pengamatan yang lain pada suatu model regrei. Model regresi yang baik adalah model regresi yang tidak terjadi heteroskedastisitas atau berjenis homokedastisitas. Pada penelitian ini pengujian heteroskedastisitas dilakukang dengan uji Glesjer yang mana merupakan uji yang dilakukan terhadap variabel bebas untuk meregresi nilai 
absolut residual. Indikasi terjadinya heteroskedastisitas yaitu apabilasecara statistik variabel bebas signifikan mempengaruhi variabel terikat. Apabila nilai probabilitas signifikansi yang dimiliki di atas tingkat kepercayaan 5 persen, maka Vvriabel bebas dikatakan tidak signifikan mempengaruhi variabel terikat.

Analisis regresi berganda digunakan untuk mengetahui pengaruh variabel bebas (independen) terhadap variabel terikat (dependen). Persamaan regresi linier berganda ini dirumuskan sebagai berikut:

$$
Y=a+b_{1} X_{1}+b_{2} X_{2}+b_{3} X_{3}+e
$$

Keterangan:

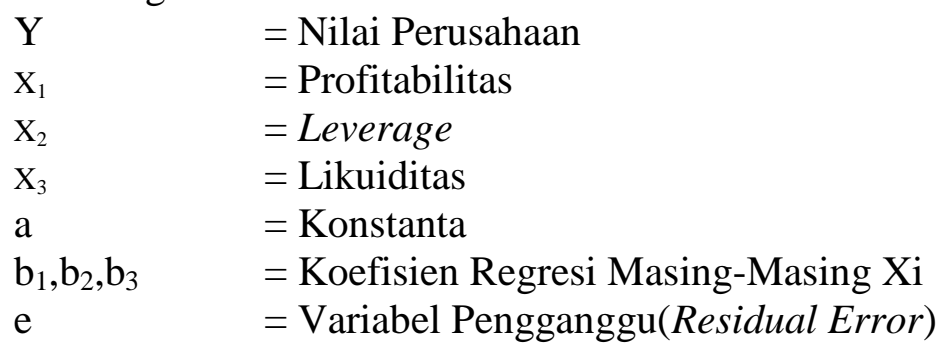

Pengujian hipotesis dilakukan melihat nilai dari uji $F$ dan uji t.Uji $F$ bertujuan untuk membantu peneliti menguji apakah dalam model regresi variabel independen secara bersama-sama atau simultan mempengaruhi variabel dependen. Pengujian hipotesis diterima apabila $\mathrm{F}$ value $\leq 0,01 ; 0,05 ; 0,1$ sebaliknya apa bila F value $\geq 0,01 ; 0,05 ; 0,1$ maka hipotesis ditolak. Uji t bertujuan untuk membantu peneliti menguji apakah dalam model regresi variabel independen secar parsial mempengaruhi variabel dependen. Pengujian hipotesis diterima apabila $\mathrm{P}$ value $\leq$ 0,$01 ; 0,05 ; 0,1$ sebaliknya apa bila $\mathrm{P}$ value $\geq 0,01 ; 0,05 ; 0,1$ maka hipotesis ditolak. Koefisien determinasi membantu peneliti untuk mengetahui seberapa besar variabel dependen dapat dijelaskan oleh variabel independen. Semakin tinggi nilai $\mathrm{R}^{2}$ suatu model maka semakin baik model regresi tersebut. 


\section{HASIL DAN PEMBAHASAN}

Tabel 2.

Hasil Analisis Statistik Deskriptif

\begin{tabular}{lrrrrr}
\hline \multicolumn{5}{c}{ Descriptive Statistics } \\
\hline Nilai Perusahaan & N & Minimum & Maximum & \multicolumn{1}{c}{ Mean } & \multicolumn{1}{c}{ Std. Deviation } \\
Profitabilitas & 36 & 63.00 & 4867.00 & 657.4444 & 1090.00583 \\
Leverage & 36 & 5.74 & 143.53 & 24.7235 & 28.32710 \\
Likuiditas & 36 & 18.00 & 303.00 & 104.2500 & 55.84487 \\
\hline Valid N (listwise) & 36 & 51.39 & 760.39 & 225.6630 & 152.33660 \\
\hline Sumber & 36 & & &
\end{tabular}

Sumber: Data Diolah, 2018

Tabel 2 menunjukkan terdapat 36 sampel data yang digunakan dalam penelitian ini, terdiri dari 12 perusahaan yang dikalikan dengan periode penelitian dari 2014-2016 (selama 3 tahun). Pada penelitian ini nilai perusahaan disimbolkan dengan Y yang diproksikan dengan Price Book Value (PBV). Berdasarkan analisis statistik deskriptif pada tabel 2 menunjukkan nilai rata-rata nilai perusahaan (Y) pada perusahaan sub sektor food and beverages di BEI periode 2014-2016 sebesar 657,44 persen dengan standar deviasi sebesar 1090 persen. Nilai terendah dari nilai perusahaan (Y) adalah 63 persen dimiliki oleh Wilmar Cahaya Indonesia Tbk. (CEKA) pada tahun 2015, sedangkan nilai tertinggi dari nilai perusahaan (Y) adalah 4867 persen dimiliki oleh PT Multi Bintang Indonesia Tbk. (MLBI) pada tahun 2014.

Penelitian ini memilihreturn on equity (ROE) yang merupakan proksi dari profitabilitas disimbolkan dengan $X_{1}$. Nilai rata-rata profitabilitas $\left(X_{1}\right)$ pada perusahaan sub sektorfood and beverages di BEI pada tahun 2014-2016 sebesar 24,72 persen dengan standar deviasi sebesar 28,32 persen. Nilai terendah dari profitabilitas $\left(\mathrm{X}_{1}\right)$ adalah 5,74 persen dimiliki oleh Sekar Bumi Tbk. (SKBM) 
pada tahun 2016, sedangkan nilai tertinggi dari profitabilitas $\left(\mathrm{X}_{1}\right)$ adalah 143,53 persen dimiliki oleh PT Multi Bintang Indonesia Tbk. (MLBI) pada tahun 2014.

Leveragedisimbolkan dengan $\mathrm{X}_{2}$ yang diproksikan dengan debt to equity ratio(DER). Berdasarkandata pada tabel 2 menunjukkan nilai rata-rata leverage $\left(\mathrm{X}_{2}\right)$ pada perusahaan sub sektorfood and beverages di BEI pada tahun 2014-2016 sebesar 104,25 persen dengan standar deviasi sebesar 55,84 persen. Nilai terendah dari leverage $\left(\mathrm{X}_{2}\right)$ adalah 18 persen dimiliki oleh Delta Djakarta Tbk. (DLTA) pada tahun 2016, sedangkan nilai tertinggi dari leverage $\left(\mathrm{X}_{2}\right)$ adalah 303 persen dimiliki oleh PT Multi Bintang Indonesia Tbk. (MLBI) pada tahun 2014.

Likuiditas disimbolkan dengan $\mathrm{X}_{3}$ yang diproksikan dengan current ratio. Berdasarkan analisis statistik deskriptif pada tabel 2 menunjukkan nilai rata-rata likuiditas $\left(\mathrm{X}_{3}\right)$ pada perusahaan sub sektorfood and beverages di BEI pada tahun 2014-2016 sebesar 225,66 persen dengan nilai standar deviasi yaitu sebesar 152,33 persen. Nilai terendah dari likuiditas $\left(X_{3}\right)$ adalah 51,39 persen dimiliki oleh PT Multi Bintang Indonesia Tbk. (MLBI) pada tahun 2014, sedangkan nilai tertinggi dari likuiditas $\left(\mathrm{X}_{3}\right)$ adalah 760,39 persen dimiliki oleh Delta Djakarta Tbk. (DLTA) pada tahun 2016.

Berdasarkan data pada tabel 3, nilai koefisien Asymp. Sig. (2-tailed)yaitu sebesar 0,341 memiliki nilai yang lebih besar dari nilai signifikansi yang digunakan yakni sebesar $0,05(0,148>0,05)$. Hasil inimenunjukkan bahwa terjadinya distribusi normal pada data yang digunakan dalam penelitian ini. 
Tabel 3.

Hasil Uji Normalitas

\begin{tabular}{|c|c|c|}
\hline & & $\begin{array}{c}\text { Unstandardized } \\
\text { Residual }\end{array}$ \\
\hline$N$ & & 36 \\
\hline \multirow{3}{*}{ Normal Parameters ${ }^{a, b}$} & Mean & $0 \mathrm{E}-7$ \\
\hline & Std. Deviation & 1428.19238385 \\
\hline & Absolute & .156 \\
\hline \multirow[t]{2}{*}{ Most Extreme Differences } & Positive & .107 \\
\hline & Negative & .156 \\
\hline Kolmogorov-Smirnov $Z$ & & .939 \\
\hline Asymp. Sig. (2-tailed) & & .341 \\
\hline $\begin{array}{l}\text { a. Test distribution is Norn } \\
\text { b. Calculated from data. }\end{array}$ & & \\
\hline
\end{tabular}

Tabel 4.

Hasil Uji Autokorelasi

\begin{tabular}{lrrrrr}
\hline Model & R & R Square & $\begin{array}{c}\text { Adjusted R } \\
\text { Square }\end{array}$ & $\begin{array}{c}\text { Std. Error of the } \\
\text { Estimate }\end{array}$ & Durbin-Watson \\
\hline 1 & $0,985^{\mathrm{a}}$ & 0,970 & 0,967 & 493,6395 & 2,014 \\
\hline
\end{tabular}

Sumber: Data Diolah, 2018

Nilai Durbin - Waston $(D W)$ pada tabel 4 yaitu sebesar 2,014. Berdasarkan tabel DW pada tingkat signfikansi sebesar 0,05 dan jumlah variabel bebas sebanyak $3(k=3)$ dengan jumlah sampel sebanyak $36(n=36)$. Nilai $d_{L}=1,295$ dan $\mathrm{d}_{\mathrm{U}}=1,653$ sehingga $4-\mathrm{d}_{\mathrm{U}}=4-1,653=2,347$. Nilai DW sebesar 2,014 yang lebih besar dari batas atas $\left(d_{U}\right)$ sebesar 1,653 dan kurang dari 4- $d_{U}$ sebesar 2,347 memiliki arti bahwa model regresi yang digunakan pada penelitian ini bebas dari autokorelasi atau tidak terjadi autokorelasi.

Tabel 5.

Hasil Uji Multikolinearitas

\begin{tabular}{|c|c|c|}
\hline Variabel & VIF & Keterangan \\
\hline Profitabilitas & 2.059 & $\begin{array}{l}\text { Tidak ada gejala } \\
\text { multikolinieritas }\end{array}$ \\
\hline Leverage & 3.490 & $\begin{array}{l}\text { Tidak ada gejala } \\
\text { multikolinieritas }\end{array}$ \\
\hline Likuiditas & 2.105 & $\begin{array}{l}\text { Tidak ada gejala } \\
\text { multikolinieritas }\end{array}$ \\
\hline
\end{tabular}

Sumber: Data Diolah, 2018 
Berdasarkan data pada tabel 5 menunjukkan bahwa nilai koefisien torelance dari setiap variabel yang digunakan seperti profitabilitas $\left(\mathrm{X}_{1}\right)$, leverage $\left(\mathrm{X}_{2}\right)$, dan likuiditas $\left(\mathrm{X}_{3}\right)$ memiliki nilai yang lebih besar atau sama dengan 0,10 dan nilai varian infltation factor (VIF) yang lebih kecil atau sama dengan 10.Hal ini berarti tidak terdapat gejala multikoleniaritas antar variabel pada model regresi yang digunakan pada penelitian ini.model regresi yang digunakan pada penelitian ini

Tabel 6.

Hasil Uji Heteroskedasitas

\begin{tabular}{ccc}
\hline Variabel & Nilai Signifikansi & Keterangan \\
\hline Profitabilitas & 0,183 & $\begin{array}{c}\text { Tidak ada gejala } \\
\text { heteroskedastisitas } \\
\text { Tidak ada gejala } \\
\text { Leverage }\end{array}$ \\
Liqiuditas & 0,197 & $\begin{array}{c}\text { Tidak ada gejala } \\
\text { heteroskedastisitas }\end{array}$ \\
\hline
\end{tabular}

Sumber: Data Diolah, 2018

Berdasarkan hasil olahan data pada tabel 6 menunjukkan bahwa tidak ada variabel independen yang signifikan. Hal tersebut dapat dilihat dari nilai koefisien probabilitas signifikansi yang lebih tinggi apabila dibandingkan dengan signifikansi yang digunakan yaitu 5 persen $(0,05)$. Ini berarti bahwa tidak terjadi heteroskedastisitas pada model regresi yang digunakan.

\section{Tabel 7.}

Hasil Uji Analisis Regresi Linear Berganda

\begin{tabular}{ccccc}
\hline $\begin{array}{c}\text { Variabel } \\
\text { Terikat }\end{array}$ & Variabel Bebas & $\begin{array}{c}\text { Koefisien } \\
\text { Regresi }\end{array}$ & t-hitung & Sig. \\
\hline & $\mathrm{X}_{1}$ & 71,556 & 22,824 & 0,000 \\
$\mathrm{Y}$ & $\mathrm{X}_{2}$ & $-1,412$ & 0,790 & 0,436 \\
& $\mathrm{X}_{3}$ & 0,529 & 1,276 & 0,031 \\
\hline & Constanta $=646,021$ & & \multicolumn{2}{c}{ F Hitung $=345,177$} \\
& R Square $=0,970$ & & Signifikansi $=0,000$
\end{tabular}

Sumber: Data Diolah, 2018

Persamaan regresi yang digunakan dalam penelitian ini berdasarkan hasil analisis data regresi linear berganda pada tabel 7 adalah sebagai berikut. 


$$
Y=646,021+71,556 X_{1}-1,412 X_{2}+0,529 X_{3}
$$

Keterangan :

$\mathrm{Y}=$ Nilai Perusahaan

$\mathrm{X}_{1} \quad=$ Profitabilitas

$\mathrm{X}_{2} \quad=$ Leverage

$\mathrm{X}_{3} \quad=$ Likuiditas

Persamaan regresi tersebut menunjukkan arah masing - masing pengaruh variabel bebas terhadap variabel terikat. Koefisien regresi variabel bebas yang bertanda negatif mengindikasikan adanya pengaruh berlawanan arah terhadap variabel terikat. Koefisien regresi variabel yang bertanda positif mengindikasikan adanya pengaruh searah terhadap variabel terikat.

Nilai konstanta sebesar 646,021 menunjukkan bahwa jika profitabilitas, leverage, likuiditas serta interaksinya dianggap konstan maka nilai perusahaan yang diperoleh sebesar 646,021 persen.Nilai koefisien regresi profitabilitas $\left(\mathrm{X}_{1}\right)$ sebesar 71,556 menunjukkanketika profitabilitas mengalami peningkatan sebesar satu persen maka akan diikuti dengan kenaikan nilai perusahaan sebesar 71,556 dengan adanya asumsi bahwa variabel lain tidak mengalami perubahan atau konstan. Leverage $\left(\mathrm{X}_{2}\right)$ memiliki nilai koefisien regresi sebesar -1,412 yang berarti bahwa ketika leverage mengalami peningkatan sebesar satu persen, maka hal tersebut akan diikuti dengan terjadinya penurunan sebesar -1,412 pada nilai perusahaan dengan asumsi bahwa variabel lainnya tidak mengalami perubahan atau konstan. Nilai koefisien regresi likuiditas (X3) sebesar 0,529 memiliki makna bahwa ketika terjadi kenaikan sebesar satu persen likuiditas maka akan diikuti dengan kenaikan pada nilai perusahaan sebesar 0,529.persen dengan asumsi 
bahwa variabel lainnya tidak mengalami perubahan atau konstan.sar 0,529 persen dengan asumsi bahwa variabel lain tidak mengalami perubahan atau konstan.

Hasil uji F yang dapat dilihat pada tabel 7. menunjukkan bahwa probabilitas signifikansi yaitu sebesar $0,000<(0,05)$, maka dapat ditarik kesimpulan bahwaH $\mathrm{H}_{0}$ ditolak dan $\mathrm{H}_{1}$ diterima. Hal ini berarti bahwa variabel profitabilitas, leverage, dan likuiditas secara simultan berpengaruh signifikan terhadap nilai perusahaan.Nilai $R$ square yaitu sebesar 0,970 atau 97 persen. Hasil tersebut menunjukkan bahwa sebesar 97 persen variasi dari variabel terikat yaitu nilai perusahaan dapat dijelaskan oleh variasi variabel bebasnya yaitu profitabilitas, leverage, dan likuiditas. Sisanya sebesar 3 persen dijelaskan oleh variabel-variabel lainnya yang tidak dimasukkan dalam model penelitian ini.

\section{Pengaruh profitabilitas terhadap nilai perusahaan.}

Berdasarkan data pada tabel 7 diketahui bahwa nilai signifikansi variabel profitabiltas yaitu sebesar 0,000. Nilai signifikansi $0,000<0,05$ menunjukkan $\mathrm{H}_{0}$ ditolak dan $\mathrm{H}_{1}$ diterima yang berarti bahwa profitabilitas memiliki pengaruh positif signifikan terhadap nilai perusahaan. Koefisien regresi profitabilitas $\left(\mathrm{X}_{1}\right)$ sebesar 71,556 menunjukkan antara profitabilitas terhadap nilai perusahaan memiliki pengaruh yang positif. Hasil tersebut mengindikaskan bahwa hipotesis pertama yang menyatakan bahwa profitabilitas berpengaruh positif signifikan terhadap nilai perusahaan diterima.

Profitabilitas yang diproksikan dengan return on equity (ROE) pada perusahaan sub sektor food and beverage di BEI periode 2014-2016 memiliki pengaruh positif signifikan terhadap nilai perusahaan, ini berarti bahwa 
profitabilitas yang semakin tinggi akan membuat nilai perusahaan juga akan meningkat, begitupula sebaliknya. Profitabilitas yang tinggi mencerminkan kemampuan perusahaan dalam menghasilkan keuntungan yang tinggi bagi pemegang saham. Perusahaan akan mampu menarik minat investor untuk menanamkan modalnya pada perusahaan ketika profitabilitas yang dimiliki perusahaan tinggi. Harga saham akan menjadi tinggi ketika minat dari para investor untuk menanamkan modalnya pada perusahaan tinggi akibat dari nilai ROE yang tinggi.Profitabilitas dengan harga saham yang memiliki hubungan positif ini membuat tingginya harga saham akan mempengaruhi nilai yang dimiliki oleh perusahaan.

Laba per lembar saham (EPS/Earning Per Share) perusahaan juga akan meningkat ketika profitabilitas yang dimiliki perusahaan semakin tinggi. Peningkatan EPS akan membuat investor tertarik menanamkan modalnya dengan membeli saham perusahaan. Nilai perusahaan akan meningkat ketika banyaknya jumlah investor yang tertarik untuk membeli saham perusahaan yang dapat membuat naiknya harga saham perusahaan tersebut, harga saham yang tinggi akan mampu meningkatkan nilai perusahaan. Perusahaan yang memiliki kinerja keuangan yang baik dan mendapatkan keuntungan besar maka banyak investor yang ingin berinvestasi ke dalam perusahaan tersebut, dan membuat permintaan akan saham perusahaan meningkat sehingga harga saham akan naik. Profitabilitas merupakan salah satu hal yang dijadikan ukuran bagi para pemegang saham yang umumnya ingin mengetahui tingkat profitabilitas modal saham yang ditanamkan pada perusahaan dan seberapa besar keuntungan yang diperoleh dari investasi 
yang dilakukan. Ketika profitabilitas meningkat maka investor akan semakin tertarik untuk menanamkan modalnya.Cecilia dan Zainul (2015) pada penelitian yang dilakukan membuktikan bahwa profitabilitas yang memiliki pertumbuhan semakin baik menunjukkan bahwa semakin baik juga prospek yang dimiliki perusahaan di masa depan, artinya nilai perusahaan akan semakin meningkat dalam arti profit yang akan dibagi kepada pemegang saham akan meningkat. Apabila keuntungan yang diperoleh perusahaan semakin besar, maka hal ini menunjukkan bahwa perusahaan memiliki kemampuan yang semakin besar untuk membayar deviden kepada para pemegang saham. Penelitian dari Dwi dan Kurnia (2013) menemukan bahwa profitabilitas mempunyai pengaruh positif terhadap nilai perusahaan, jadi semakin besar profitabilitas yang dimiliki oleh suatu perusahaan maka semakin baik nilai yang dimiliki oleh perusahaan. Hasil penelitian lainnya yang mendukung penelitian ini adalah penelitian yang dilakukan oleh Novrianti dan Ely (2013),Sucuahi dan Cambarihan (2014), serta Winarto (2015) yang menemukan bahwa profitabilitas memiliki pengaruh positif signifikan terhadap nilai perusahaan.

\section{Pengaruh leverage terhadap nilai perusahaan.}

Berdasarkan hasil olah data pada tabel 7 dapat diketahui bahwa leverage memiliki nilai signifikansi sebesar 0,436 . Nilai signifikansi $0,436>\quad=0,05$ hal ini menunjukkan $\mathrm{H}_{0}$ diterima dan $\mathrm{H}_{2}$ ditolak yang berarti bahwa leverage tidak berpengaruh signifikan terhadap nilai perusahaan. Koefisien regresi leverage $\left(\mathrm{X}_{2}\right)$

sebesar -1,412 menunjukkan adanya pengaruh negatif antara leverage terhadap nilai perusahaan. Hasil tersebut mengindikaskan bahwa hipotesis kedua yang 
I Putu Sukarya, Pengaruh Profitabilitas, Leverage, dan Likuiditas...

menyatakan bahwa leverage berpengaruh positif signifikan terhadap nilai perusahaan ditolak.

Debt to equity ratio (DER) sebagai proksi dari leverageyang berdasarkan hasil uji tidak berpengaruh signifikan terhadap nilai perusahaan pada perusahaan sub sektor food and beverages di BEI tahun 2014-2016. Hal ini menunjukkan bahwa perusahaan dalam mendanai aktiva yang dimiliki cenderung menggunakan modal sendiri (internal financing) yang dapat berasal dari modal saham dan laba ditahan dibanding dengan menggunakan utang. Hasil penelitian lainnya yang sesuai dengan hasil temuan ini pernah diteliti oleh Kodongo et al. (2014) serta Novari dan Lestari (2016) yang menemukan bahwa leverage tidak memiliki pengaruh signifikan terhadap nilai perusahaan.

\section{Pengaruh likuiditas terhadap nilai perusahaan.}

Berdasarkan tabel 7 diketahui bahwa likuiditas memiliki nilai signifikansi yaitu 0,031 . Nilai signifikansi $0,031<=0,05$ ini menunjukkan bahwa $\mathrm{H}_{0}$ ditolak dan $\mathrm{H}_{3}$ diterima yang berarti bahwa likuiditas berpengaruh positif signifikan terhadap nilai perusahaan. Koefisien regresi likuiditas $\left(X_{3}\right)$ sebesar 0,529 menunjukkan bahwa likuiditasmemiliki pengaruh positif terhadap nilai perusahaan. Hasil tersebut mengindikaskan bahwa hipotesis ketiga yang menyatakan bahwa likuiditas berpengaruh positif signifikan terhadap nilai perusahaan diterima.

Hasil penelitian ini menunjukkan bahwa likuiditas berpengaruh positif signifikan terhadap nilai perusahaan. Hal ini berarti bahwa semakin besar likuiditas perusahaan maka perusahaan memiliki tingkat likuidasi yang baik 
untukdapat memberikan persepsi positif terhadap kondisi yang dapat meningkatkan nilai perusahaan di mata investor. Tingkat likuiditas yang tinggi menunjukkan bahwa perusahaan berada dalam kondisi yang baik yang mampu memenuhi kewajiban jangka pendeknya. Harga saham yang meningkat tentunya akan meningkatkan nilai perusahaan.

Likuiditas yang semakin tinggi membuat nilai perusahaan akansemakintinggidansebaliknya likuiditasyang semakin rendah akan menyebabkan nilai perusahaan akan semakin rendah. Hasil penelitian lainnya yang sesuai dengan penelitian ini adalah penelitian yang dilakukan oleh Anzlina dan Rustam (2013), Winarto (2015), Putra danLestari (2016), serta Jariah (2016) yang menemukan bahwa adanya pengaruh positif signifikan antara likuiditas terhadap nilai perusahaan.

\section{IMPLIKASI HASIL PENELITIAN}

Hasil penelitian ini memiliki implikasi secara teoritis dan praktis. Secara teoritis, hasil penelitian mendukung teori bahwa profitabilitas berpengaruh positif signifikan terhadap nilai perusahaan, leverage tidak berpengaruh signifikan terhadap nilai perusahaan, dan likuiditas berpengaruh positif signifikan terhadap nilai perusahaan. Hasil analisis koefisien determinasi $\left(\mathrm{R}^{2}\right)$ sebesar 0,970 atau 97 persen. Hasil tersebut memiliki arti bahwa hanya 97 persen variasi dari variabel terikat yaitu nilai perusahaan dapat dijelaskan oleh variasi variabel bebas seperti profitabilitas, leverage, dan likuiditas, sedangkan sisanya sebesar 3 persen dijelaskan oleh variabel lainnya yang tidak dimasukkan dalam model analisis. 
Secara praktis hasil penelitian ini memiliki implikasi pada informasi bagi investor dan pemegang saham bahwa profitabilitas berpengaruh positif signifikan terhadap nilai perusahaan. Hasil penelitian ini mengindikasikan implikasi penelitian yaitu semakin tingginya profitabilitas pada perusahaan food and beveragesmaka akan dapat meningkatkan nilai perusahaan. Likuiditas yang memiliki pengaruh positif signifikan terhadap nilai perusahaan mengindikasikan bahwa ketika nilai likiditas semakin tinggi maka hal tersebut akan membuat nilai perusahaan akan semakin meningkat.

\section{SIMPULAN DAN SARAN}

Berdasarkan hasil analisis data dan pembahasan maka penelitian ini dapat disimpulkan bahwa profitabilitas berpengaruh positif signifikan terhadap nilai perusahaan. Hasil penelitian ini berarti bahwa semakin tingginya nilai profitabilitas dapat mempengaruhi kenaikan nilai perusahan pada sektor food and beverages pada tahun 2014-2016. Leverageyang tidak berpengaruh signifikan terhadap nilai perusahaan memiliki arti bahwa pembahaan pada leverage tidak berpengaruh terhadap nilai perusahaan pada sub sektor food and beverages periode 2014-2016. Likuiditas berpengaruh positif signifikan terhadap nilai perusahaan. Hasil penelitian ini berarti bahwa semakin tingginya likuditas maka dapat berpengaruh pada kenaikan nilai perusahaan pada sub sektor food and beverages pada tahun 2014-2016.

Saran yang dapat diberikan berdasarkan pada hasil penelitian ini yaitu: 1) Bagi pihak perusahaan dimana perusahaan perlu memperhatikan variabel-variabel yang mempengaruhi nilai perusahaan, khususnya untuk variabel profitabilitas dan 
likuiditas karena variabel ini terbukti memiliki pengaruh signifikan terhadap nilai perusahaan, sehingga perusahaan dapat menentukan meningkatkan nilai perusahaan. 2) Bagi penelitian selanjutnya sebaiknya turut mempertimbangkan faktor-faktor lain yang dapat mempengaruhi nilai perusahaan sebagai variabel dalam penelitian, selain itu pertimbangan untuk memilih sektor lainnya di Bursa Efek Indonesia dapat digunakan dalam melakukan penelitian. 3) Bagi para investor dan calon investor yang ingin berinvestasi di perusahaan food and beverages yang terdaftar di Bursa Efek Indonesia sebaiknya memperhatikan profitabilitas dan likuiditas yang akan mampu menaikkan dan berpengaruh terhadap nilai perusahaan secara signifikan sehingga investor dan calon investor tertarik berinvestasi pada sektor food and beverages dan dapat dijadikan pertimbangan dalam pengambilan keputusan investasi yang tepat.

\section{REFERENSI}

Adegnuba, A. A., A. A. Ige, dan O. R. Kesinro. (2016). Leverage Keuangan dan Nilai Perusahaan: Studi Perusahaan Terpilih di Nigeria. European Journal of Penelitian dan Refleksi Ilmu Manajemen, 4(1), hal. 2056-5992.

Anzlina, C. W. dan Rustam. (2013). Pengaruh Tingkat Likuiditas, Solvabilitas, Aktivitas, dan Profitabilitas terhadap nilai perusahaan pada perusahaan real estate dan property di BEI tahun 2006-2008. Fakultas Ekonomi Universitas Sumatra Utara, 6(12), hal. 67 - 75.

Asif, A., dan AzizB. (2016). Impact of Capital Structurenon Firm Value CreationEvidence from the Cement Sector of Pakistan. International Journal of Research in Finance and Marketing, 6(6), pp. 231-245.

Bursa Efek Indonesia. (2018). Laporan Keuangan Tahunan periode 2014-2016. Jakarta: IDX.

Cecilia, S. R. dan Torong M. Zainul. (2015). Analisis Pengaruh Corporate Social Responsibility, Profitabilitas dan Ukuran Perusahaan Terhadap Nilai Perusahaan pada Perusahaan Perkebunan yang Go Public di Indonesia, Malaysia, dan Singapura. Jurnal Simposium Ekonomi, 8(1), hal.1-23. 
Chetty, Sukanya, Rebekah Naido, dan Yudhvir Seetharam. (2015). The Impact of Corporate Social Responsibilitynon Firms' Financial Performance in South Africa. World Journal of Management, 9(2), pp. 193-214.

Dewi, A. S. M. dan A. Wirajaya. (2013). Pengaruh Struktur Modal, Profitabilitas, dan Ukuran Perusahaan Pada Nilai Perusahaan. E-Jurnal Akuntansi Universitas Udayana, 4(2), hal. 358-372.

Du, Jinmin, Fei Wu, dan Xingyun Liang. (2016). Corporate Liquidity and Firm Value: Evidence From China's Listed Firms. EDP Sciences, 01013,pp. 1-4.

Dwi, A. dan Kurnia. (2013). Pengaruh Profitabilitas Terhadap Nilai Perusahaan: Kebijakan Dividend dan Kesempatan Investasi Sebagai Variabel Atara. Jurnal Ilmu dan Riset Akuntansi, 1(1), hal. 37-57.

Ha, N. M. dan Le M. Tai. (2017). Impact of Capital Structure and Cash Holdings on Firm Value: Case of Firm Listed on the Ho Chi Minh Stock Exchange. International Journal of Economics and Financial, 7(1), pp. 24-30.

Hartono, J. (2013). Teori Portofolio dan Analisis Investasi,Edisi Kedelapan. Yogyakarta: BPFE.

Herawati , Titin. (2013). Pengaruh Kebijakan Dividen, Kebijakan Hutang dan Profitabilitas Terhadap Nilai Perusahaan. Jurnal Manajemen, 2(2) hal. 1-18.

Husnan, S. dan Enny Pudjiastuti. (2012). Dasar-Dasar Manajemen Keuangan, Edisi Kelima. Yogyakarta: UPP STIM YKPN.

Isaac, L. (2014). Corporate Capital Structure and Firm's Market Value in Nigeria. Research Journal of Finance and Accounting, 5(14), pp. 16-31.

Jariah, Ainun. (2016). Likuiditas, Leverage, Profitabilitas Pengaruhnya Terhadap Nilai Perusahaan Manufaktur di Indonesia Melalui Kebijakan Deviden. STIE Gama Lumajang, 1(2), hal. 108-118.

Gill, Amarjit dan John D. Obradovich. (2012). The Impact of Corporate Goverance and Financial Leverage on the Value of American Firms. International Research Journal of Finance and Economics, 91, pp. 1-14.

Kodongo, O., Thabang, M., dan Leonard, M. (2014). Capital Structure, Profitabilty, and Firm Value;Panel Evidence of Listed Firms of Kenya. Munich Personal RePEc Archive, 7(6) pp. 57116. 
Moghadas, A., Pouraghajan., dan Vanoosheh, B. (2013). Impact of capital structure on firm value: Evidence from Tehran Stock Exchange. Management Science Letters, 3(6), pp. 1535-1358.

Munawaroh, A., dan Priyadi, M. P. (2014). Pengaruh Profitabilitas Terhadap Nilai Perusahaan dengan Corporate Socia; Responsibility Sebagai Variabel Moderating. Jurnal Ilmu dan Riset Akuntansi, 3(4), hal. 1-17.

Nofrita, R. (2013). Pengaruh Profitabilitas terhadap Nilai Perusahaan dengan Kebijakan Dividen sebagai Cariabel Intervening (studi empiris pada perusahaan manufaktur yang terdaftar di BEI). Jurnal Fakultas Ekonomi Universitas Negeri Padang, 1(1), hal. 1-19.

Novari, P. M. dan P. V Lestari. (2016). Pengaruh Ukuran Perusahaan, Leverage, dan Profitabilitas Terhadap Nilai Perusahaan Pada Sektor Properti dan Real Estate. E-jurnal Manajemen Unud, 5(9), hal. 5671-5694.

Novrianti K. dan K. Ely. (2015). Effect Corporate Social Responsibility on Fianncial Performance. International Journal of Economics and Financial Issues, 5(1), pp. 157-164.

Pramana, N. A. D. dan Mustanda K. (2016). Pengaruh Profitabilitas, Size Terhadap Nilai Perusahaan dengan CSR sebagai Pemoderasi. E-Jurnal Manajemen Unud, 5(1), hal. 561-594.

Prastuti, N. K. R. dan I. G. M. Sudiarta. (2016). Pengaruh Struktur Modal, Kebijakan Dividend an Ukuran Perusahaan Terhadap Nilai Perusahaan Pada Perusahaan Manufaktur. E-Jurnal Manajemen Unud, 5(3), hal. 1572-1598.

Priya, K., Nimalathasan, B., dan Piratheepan T. (2015). Impact of Capital Structure on Firm Value: Case Study of Listed Manufacturing Companies in Srilangka. Scholars World-IRMJCR, 3(1), pp. 47-53.

Putra, A. dan V. Lestari. (2016). Pengaruh Kebijakan Dividen, Likuiditas, Profitabilitas dan Ukuran Perusahaan Terhadap Nilai Perusahaan. E-Jurnal Manajemen Unud, 5(7), hal. 4044-4070.

Ramadan, I. Z. (2015). Leverage and the Jordanian Firms' Value: Empirical Evidence.International Journal of Economics and Finance, 7(4), pp. 19161971.

Rasyid, A. (2015). Effects of Ownership Structure, Capital Structure, Profitability, and Company's Growth Towards Firm Value. International Journal of Business and Management Invention, 4(4), pp. 25-31. 
Riaz, M. dan M. Qasim. (2016). Islamic Microfinance Institution: The Capital Structure, Growth, Performance, and Value of The Firm in Pakistan. Journal of ISOSS, 2(1), pp. 97-101.

Rizqia, D. A., A. Siti, dan Sumiati. (2013). Effect of Managerial Ownership, Financial Leverage, Profitability, Firm Size, and Investment Opportunity on Dividend Policy and Firm Value. Research Journal of Finance and Accounting, 4(11), pp. 120-130.

Sucuahi, W. dan Jay M. Cambarihan. (2014). Influence of Profitability to the Firm Value of Diversified Companies in the Philippines. Accounting and Finance Research, 5(2), pp. 149-153.

Sulong, Z., John C. G., H. H. Amariah, M. S.Zuraidah,dan B. M.Carl. (2013). Managerial Ownership, Leverage and Audit Quality Impact on Firm Performance: Evidence From The Malaysian Ace Market. Accounting \& Taxation Journal, 5(1), pp. 59-70.

Wiagustini, N. L. P. (2013). Dasar-Dasar Manajemen Keuangan. Denpasar: Udayana University Press.

Wijanti, N. W. N. dan I. B. P. Sedana. (2013). Pengaruh Likuiditas, Efektivitas Aktiva dan Ukuran Perusahaan Terhadap Kebijakan Deviden dan Harga Saham. Jurnal Fakultas Ekonomi Universitas Udayana, hal. 1649-1661.

Wijaya, A. dan N. Linawati. (2015). Pengaruh Kinerja Keuangan terhadap Nilai Perusahaan. FINESTA, 3(1), hal. 46-51.

Wijaya, B. dan Sedana P. (2015). Pengaruh Profitabilitas Terhadap Nilai Perusahaan (Kebijakan Deviden dan Kesempatan Investasi sebagai Variable Moderating). E-journal Manajemen Unud, 4(12), hal.4477-4500.

Winarto, J. (2015). The Determinants of Manufacturer Firm Value in Indonesia Stock Exchange. International Journal of Information, Business and Management, 7(4), pp. 323-349. 